\title{
The Developmental Potential of Frugal Innovation among Mobile Money Agents in Kitwe, Zambia
}

\begin{abstract}
Existing conceptual debates on frugal innovation have either welcomed its contribution to development or have stressed its exploitative capitalist underpinnings. Based on a qualitative survey among 52 mobile money agents and tellers in Kitwe, Zambia, the developmental potential of frugal innovation will be empirically assessed. Can the frugal innovation of mobile money become an inclusive innovation for the agents and tellers in Kitwe? This question will be tackled by focusing on entrepreneurship and labour relations. It is argued that mobile money can indeed generate employment and foster entrepreneurship, but that it can simultaneously contribute to informalisation and create new socio-economic inequalities. Empirical studies, thus, provide an opportunity to reach a more nuanced understanding of the relationship between frugal innovation and development.
\end{abstract}

In addition to extending financial services to the poor, mobile money is expected to improve productivity, by increasing the efficiency and lowering the cost of transactions, improving security, generating new employment opportunities, and creating a platform on which other businesses can grow (Donovan, 2012: 62).

Mobile money, especially the example of M-PESA in Kenya, has been hailed as a success story of frugal innovation on the African continent (Paunov, 2013; Knorringa et al., 2016). Frugal innovation, a recent innovation manifestation which is said to be disruptive of innovation processes, business models and even entire economies, can be defined as 'the stripping and/or (re)design of products, systems or services to make them affordable for low-income customers, without sacrificing user value' (Peša, 2014). If mobile money can cut the costs of transactions and expand financial inclusion, boost economic productivity, foster business growth and generate employment, then it is indeed the quintessential example of frugal innovation. Existing studies on frugal innovation and development have been ideologically polarised. On the one hand 'a business view of 'win-win' in which companies can earn profits while simultaneously alleviating poverty' has been proposed, whereas on the other hand 'critics argue that frugal innovation will merely exacerbate capitalist exploitation and inequality' (Knorringa et al., 2016: 144). Whether frugal innovation can lift the Bottom of the Pyramid (BoP) out of poverty through consumption and entrepreneurship or whether it will cause informalisation, aggravate socio-economic inequalities and drive a deeper wedge between developing and developed countries has so far remained a predominantly conceptual question (Chataway et al., 2014; Heeks et al., 2014). Yet 'only through detailed empirical studies can the developmental potential of frugal innovation be properly assessed' (Knorringa et al., 2016: 150). This article presents one empirical case through which to approach such debates. Based on a 
qualitative survey among 52 mobile money agents and tellers in Kitwe, Zambia, it poses the question whether the frugal innovation of mobile money can become an inclusive innovation.

Mobile money offers a 'faster, cheaper, and more efficient way (...) of moving money' (Hughes and Lonie, 2007: 81). Mobile money is a frugal innovation as it provides a simple but effective technology for financial transactions, which radically reduces costs and serves a mass market. Because such a large proportion of the African population remains unbanked, the potential contribution of mobile money to financial inclusion and economic development has been widely proclaimed (Donovan, 2012). Mobile money kiosks have been established in remote rural areas, in peri-urban areas and in informal urban settlements, enabling customers to make financial transactions over long distances, for example by sending money to friends and relatives, conducting business transactions or by buying airtime and paying utility bills (Finscope, 2015). Mobile phone access has increased rapidly over the last five years - in Zambia at least 77 percent of the population has access to a mobile phone - so entry barriers to use mobile money are low, especially as some services merely require identity documentation for transactions (Habeenzu, 2010). Because mobile money in Zambia has only recently started to reach a mass market, its impact can still be well discerned. In 201514.0 percent of the Zambian population was using mobile money services, of which there are three providers: Airtel, MTN and Zoona (Finscope, 2015). Whereas network operators and mobile money customers have been well studied (Hughes and Lonie, 2007; Morawczynski, 2009), mobile money agents and tellers have received relatively less attention. The view even exists that 'agents are (...) passive distributors of the product or service: a channel rather than an actor' (Foster and Heeks, 2013: 298). Yet by spreading mobile money services to a broad customer base, agents are a crucial link between network operators and customers. One fruitful angle from which to study the role of agents is that of entrepreneurship and labour relations. Mobile money providers, Zoona in particular, prominently advertise stories of successful agents and assert that agents can be (re)made into 'entrepreneurs', because the company offers them 'an opportunity to build their own businesses and create wealth and employment by providing mobile payment solutions, financial services, business management tools and support' (http://www.kiva.org/partners/210). Rather than simply accepting such claims, it should be questioned whether mobile money services are able to generate sustainable employment and entrepreneurship. Can the frugal innovation of mobile money become an inclusive innovation for the agents and tellers in Kitwe, Zambia?

Inclusive innovation can be defined as 'the development and implementation of new ideas which aspire to create opportunities that enhance social and economic well-being for disenfranchised members of society' (George et al., 2012: 663). Because 'technological progress and innovation' shape and substantially alter 'how labour and capital are deployed within an economy', this impacts on the distribution of income and processes of socio-economic development (Paunov, 2013: 9). Whether 
innovation works to increase or decrease inequality depends on the innovation itself and on the socioeconomic setting within which the innovation is introduced. Studying employment generation and entrepreneurship among mobile money agents in Kitwe provides insights into aspects of inclusiveness. Mobile money providers advertise stories of previously disenfranchised individuals who have become successful agents. But mobile money penetration might give rise to new inequalities, among agents and between agents and tellers. This article suggests that frugal innovation can simultaneously have divergent developmental outcomes: it can generate employment and foster entrepreneurship, but it can also contribute to informalisation and create new socio-economic inequalities (Dolan and Rajak, 2016). Empirical studies thus provide an opportunity to reach a more nuanced understanding of the relationship between frugal innovation and development (Knorringa et al., 2016).

This paper is structured as follows: First, an overview will be given of debates on mobile money, agents and entrepreneurship, highlighting linkages to frugal and inclusive innovation literature. Secondly, the context of mobile money in Kitwe, Zambia, will be sketched and the methodology of this study will be explained. In the third section the results of the survey among Kitwe's agents and tellers will be discussed. In the fourth section these results will be linked to debates on entrepreneurship, labour relations and inclusive innovation. Section five concludes.

\section{Mobile Money, Agents and Entrepreneurship: Some Debates}

Mobile phones, by facilitating communication and enabling capital formation, have been identified as 'a key innovative technology in support of livelihoods', notably in ICT4D (Information and Communication Technology for Development) debates (Duncombe, 2014: 567). Similarly, it has been asserted that mobile money 'will undoubtedly positively impact the course of economic growth in emerging markets', as it reduces the costs of money transfers and thereby induces savings, investments and remittances, bolsters businesses and boosts employment (Gencer, 2010: 102). Mobile money transfers are a uniquely African innovation, born out of the practice of transferring mobile phone credit through SMS (Omwansa and Sullivan, 2012). The first mobile money service, M-PESA, introduced in Kenya by Safaricom in 2007, rapidly obtained a mass market. Only five years after its launch, 70 percent of Kenyan households had access to M-PESA and there were over 35,000 agents countrywide (Jack et al., 2013: 356). Because formal financial services, especially banks, remain largely out of reach of rural and poorer urban Africans, mobile money has been hailed as one means of bringing these un(der)served customers within the reach of financial services, 'banking the unbanked' (Aker and Mbiti, 2010). Part of the attraction of mobile money services is that they are relatively convenient and cheap: they allow users to transfer money to others, make deposits and withdrawals, pay bills and purchase mobile phone credit (Morawczynski, 2009) 
and they have lower transaction costs than alternative services, such as banks or sending money by bus (Jack and Suri, 2011). Consequently, strong assertions about the 'transformational' potential of mobile money have been advanced, based on claims that mobile money might 'revolutionise' money transfers, financial transactions and even entire economies on the African continent (Morawczynski, 2009; Heeks, 2014).

Whereas some studies endorse the positive contributions of mobile money to economic development (in terms of income generation, consumption and employment), 'questions remain regarding the nature and extent of m-money's effect on the welfare of poor users in developing countries' (Aker and Mbiti, 2010: 222). It should therefore be empirically ascertained how mobile money will affect social divisions of gender, wealth and rural-urban residence. Duncombe (2012: 369) more cautiously stresses that 'early adoption of $\mathrm{m}$-finance has favoured those already financially included and marketdriven solutions for the financially excluded are limited.' Some authors claim that rather than enhancing development and contributing to inclusion, mobile money and its capitalist underpinnings will merely aggravate the exploitation of the poor, by exacerbating societal and global inequalities (Ya'u, 2004; Murphy et al., 2014). Murphy et al. (2014: 265) assert that narratives of financial inclusion and promises of economic development through ICTs 'often overlook the interdependencies and power relations that mediate the potential for African societies to empower themselves within the GIE [global information economy], contingent relations that may exclude some economic actors whilst including, connecting and sometimes exploiting others.' Ya'u (2004: 12) critically argues that the digital divide 'defined as unequal access to ICTs within and between nations' is expanding rather than closing, because it 'is part of the wider development divide.' Such existing debates about the developmental potential of mobile money have remarkable parallels to previously mentioned polarising narratives of frugal innovation and inclusive development (Chataway et al., 2014). By empirically engaging with the example of mobile money agents and tellers in Kitwe, this study can contribute to debates on whether mobile money (as an example of frugal innovation) has led to inclusive development, or whether it has merely caused informalisation and a deepening of the 'digital divide' (Heeks et al., 2014).

One useful perspective from which to complicate narratives on frugal innovation, mobile money and development is that of labour relations and entrepreneurship (Meagher et al., 2016). Attention should be paid to the dynamics through which 'global currents in products, services, information and ideologies', might reshape terms of employment and induce local vulnerabilities (Arora and Romijn, 2012: 481). Although mobile money can provide employment prospects, as well as access to skills, capital and technology, Meagher et al. (2016: 471) have argued that 'global labour linkages have tended to increase rather than reduce problems of vulnerable and unstable working conditions within African countries.' Critically unpacking the narratives of 'entrepreneurship' among Zambian mobile money agents and 
paying attention to the unequal labour relations between agents and tellers can contribute to debates about mobile money, frugal innovation and inclusive development (Knorringa et al., 2016). Whereas a number of studies have been conducted on network operators, such as Vodafone and Airtel (Hughes and Lonie, 2007), and on the role of users in appropriating mobile financial services (Morawczynski, 2009), mobile money agents and tellers - in particular their labour relations - have been largely overlooked. Duncombe (2014: 573) notes that mobile money agents 'play an important role in delivering services', yet there 'is little evidence from the literature concerning their impact on livelihoods.' This is all the more surprising given that agents are crucial intermediaries between network operators and customers. Agents provide access to mobile financial services through their outlets, they facilitate transactions by managing cash and float and they familiarise first-time users with mobile money transactions, which establishes trust and expands the customer base (Interview \#12, Zoona agent manager). ${ }^{1}$ Although mobile money providers have celebrated the role of agents in generating employment and fostering entrepreneurship, this has been the focus of few empirical studies so far (Foster and Heeks, 2013; Dolan and Rajak, 2016). Can mobile money indeed contribute to employment generation, entrepreneurship and inclusive innovation? Certain agents have managed to start their own businesses, to open multiple outlets and earn high profits. Yet there is a discrepancy between the fortune of agents and tellers. Tellers, who are employed by agents, carry out mobile money transactions and are responsible for customer relations, they make long hours in the kiosks, yet they are poorly paid and they rarely have a formal contract (Interview \#2, Zoona manager). Labour conditions among tellers therefore suggest that 'there are clear limitations to the transformational potential of mobile financial services' (Morawczynski, 2009: 521).

Airtel, MTN and Zoona have portrayed mobile money agents as entrepreneurs who can contribute to economic growth and poverty reduction by running profitable businesses (Dolan and Rajak, 2016). Zoona, in particular, depicts 'emerging entrepreneurs' as people 'who dream of starting or growing a business and through personal success can effect real change, drive progress and develop themselves and their communities.' By supporting and unlocking the 'untapped potential' of these entrepreneurs, Zoona allows them to 'earn revenue, create jobs and invest in their communities, resulting in both employment and empowerment' (https://www.bcorporation.net/community/zoona). Following the pioneering work of Schumpeter (1934), economic thought has attributed a transformative role to entrepreneurship in effecting economic change. Entrepreneurship has recently started to receive much attention as a strategy to alleviate poverty (Hall et al., 2012; Alvarez and Barney, 2014). Entrepreneurship might be defined as 'the discovery, evaluation, and exploitation of future goods and services' (Eckhardt and Shane, 2003: 336). As 'opportunity entrepreneurs' mobile money agents reacted to a new market opportunity. Whilst first movers acted on 'discovery opportunities', created by technological change and the introduction of mobile money services into the market, subsequent mobile money agents have attempted to consolidate 
'creation opportunities', which can serve to build new markets, generate sustained competitive advantage and raise profits (Alvarez and Barney, 2014). Some mobile money agents have succeeded in creating new markets, generating high profits (up to $\mathrm{K} 60,000$ per month $^{2}$ ) and consolidating their competitive advantage through business skills. Entrepreneurship can, in this sense, be good for economic growth. Acs (2006: 97) asserts that 'entrepreneurs create new businesses, and new businesses in turn create jobs, intensify competition, and may even increase productivity through technological change.' In this connection, 'improvements in information technologies such as telecommunications [and mobile money] may increase the returns to entrepreneurship' (Acs, 2006: 100). More critical studies question the relationship between mobile money and entrepreneurship, arguing that the discourse of entrepreneurship might mask, or even aggravate, structural socio-economic inequalities (Murphy et al., 2014). Dolan and Rajak (2016: 515) see mobile money as an 'engine of jobless growth, offering contingent opportunity in place of secure employment.' They assert that 'the experience of entrepreneurship may deliver precisely the opposite of what inclusive business implies', resulting in displacement and inequality, as the labour conditions of tellers suggest (Dolan and Rajak, 2016: 527). It must therefore be questioned what results entrepreneurship has (on an individual and a broader socio-economic level) and what this implies for the developmental potential of mobile money agents and their businesses. Whether mobile money will prove to be an inclusive innovation from the perspective of labour relations and entrepreneurship can only be assessed empirically. Some background on mobile money services in Kitwe, Zambia, and on the methodology of this study, first has to be provided.

\section{A Background to Mobile Money in Kitwe, Zambia}

Zoona, which started as a payment system for cotton farmers, was the first company to effectively launch mobile financial services in Zambia in 2009. Offering an interoperable network service, Zoona is one of the few mobile financial services on the African continent that has remained independent of telecom providers (Interview \#2, Zoona manager). This implies that Zoona relies solely on mobile money transactions for its profits, as it has no other revenue streams. The company initially struggled to reach commercial viability and scale, relying on external grants to make ends meet. In Kitwe, Zambia's second largest city, kiosks only opened in 2011. In 2012 telecom providers Airtel and MTN also started to offer mobile money services, thereby diversifying the playing field and increasing the customer base (Interview \#1, Mobile technology professional). In 2015, the market share of Zoona agents was estimated at 33 percent, whereas Airtel and MTN both held 27 percent of the national mobile money market (http://www.helix-

institute.com/sites/default/files/Publications/160126\%20Zambia\%20Country\%20Report\%20UNCDF\%20 
Helix\%20FINAL\%20(1)_0.pdf). The main difference between the three providers is that Zoona works without customer accounts - transactions only require valid identity documentation and a personalised PIN. Airtel and MTN, contrastingly, aim to create a 'network effect' through customer accounts customers cannot send money without an account, higher fees are charged when transacting money to non-users and intensive marketing and promotions are used to attract customers to join the network (Interview \#11, MTN agent manager; Donovan, 2012). Since 2012 mobile money transfers in Zambia have experienced steady growth rates, booming from early 2014 onwards. ${ }^{3}$ A Finscope (2015) study estimated that 14.0 percent of the population makes use of mobile money, but the figure might well be much higher by now (Kabala and Seshamani, 2016).

The majority of Zambian adults (61.8 percent) lack access to formal financial services, bank accounts in particular (Finscope, 2015). Especially among those who are in informal employment, agriculture or trade, cash remains of paramount importance to any kind of financial transaction. Mobile money has proved a convenient service because of its various uses, ranging from sending and receiving money to/from friends and relatives, to business transactions, paying utility bills, buying mobile phone credit or paying school fees (Kabala and Seshamani, 2016). To transfer money individuals deposit cash at an agent's outlet. The agent converts the cash into e-value (float), which can be transferred to a recipient's phone through a SMS message, containing a unique transaction code. To convert the e-value back into cash, the recipient visits an agent of the same provider and withdraws the money (Maurer et al., 2013). Mobile money thus revolves around the exchange of cash and e-value, which is mediated by agents (Jack et al., 2013). This has caused a degree of financial 'formalisation', 'a shift from informal exchange (through personal remittances, for example) to greater formality through the use of agents' (Duncombe, 2012: 571). One agent in Kitwe asserted that from a user perspective, the change from interpersonal money transfer in cash to the introduction of intermediaries in the form of agents and virtual money transfer has been the most impactful shift accompanying mobile money services (Interview \#6, Zoona agent). By connecting users to providers, establishing trust in the system and managing mobile money outlets, agents and tellers play a pivotal role in mobile money services.

Mobile money outlets in Zambia are part of larger franchises, which profoundly influences labour relations and opportunities for entrepreneurship. Franchising is a contractual arrangement by which the franchisor (Airtel, MTN or Zoona) contracts individual retailers (agents), offering them dealership of products and services (mobile money) and use of the business format and brand name, in exchange for fees and payments (a share of commissions) (Sigué, 2012: 168). In this set-up, Airtel, MTN and Zoona give the right to use their brand name to individual mobile money agents, who function as independent retailers. Agents have a contractual relationship to Airtel, MTN or Zoona and surrender a share of commissions to the company (See Table 1). Despite the rhetoric of entrepreneurship, agents have never 
been able to single-handedly manage mobile money outlets. In busy outlets agents could not serve all customers by themselves, but more importantly, many agents were not prepared to sit in a kiosk full-time. Soon the informal practice of hiring 'tellers', who attend to customers and conduct all daily transactions and services, was born. Whereas agents have a contractual relationship to the mobile money provider, tellers do not. Instead, they are directly hired by managing agents, which results in long working hours and poor remuneration. Even if mobile money providers initially disapproved of this practice, it proved a convenient way to scale and the franchising structure left providers with few tools to directly intervene in agent businesses (Interview \#3, Zoona customer representative). The franchising structure also enables agents to open multiple outlets. Most agents have between one and three mobile money outlets (with two or three tellers per outlet). The biggest mobile money agent in Kitwe has thirteen outlets and employs twenty-five tellers, but this is the exception rather than the rule. The franchising structure and the attendant discrepancy between agents and tellers influence mobile money businesses, labour relations and entrepreneurship in Kitwe.

The city of Kitwe on the Zambian Copperbelt was chosen as a site to engage with frugal and inclusive innovation, labour relations and entrepreneurship among mobile money agents and tellers. Given high unemployment rates, prospects of employment generation and entrepreneurship through mobile money are particularly welcome in Kitwe. Although the number of outlets has increased rapidly from 2014 onwards, there is still much scope for the expansion and scaling of mobile money throughout Kitwe (Interview \#12, Zoona agent manager). After having read secondary literature on mobile money, frugal and inclusive innovation and entrepreneurship, a qualitative survey for mobile money agents and tellers (Airtel, MTN and Zoona) was designed to tackle the questions: Can mobile money generate entrepreneurship among the agents and tellers in Kitwe? If so, what kind of entrepreneurship is this and who is able to reap its benefits? A qualitative survey, with open-ended questions, was employed as this can determine variation and diversity within a population and it can shed light on meanings and experiences (Jansen, 2010). The survey explored certain predefined topics, which were expected to have a bearing on entrepreneurial ability (such as age; educational and employment background; the process of starting the job and setting up the business; capital formation, training and support; customer relations, transactions and profits) but it also examined attitudes related to entrepreneurship (benefits and difficulties of being an agent or teller, views on the mobile money business and future plans).This range of topics was meant to establish the empirical diversity in entrepreneurial trajectories among agents and tellers in Kitwe. Between July and September 2015, 52 mobile money agents and tellers completed the survey through interviews, which lasted approximately one hour. ${ }^{4}$ The survey was selectively sampled, aiming to provide a spread between agents (23) and tellers (29), mobile money providers (Zoona 24; Airtel 12; MTN 16) and location (city centre 22; residential areas 12; informal settlements 18). The 
survey results are summarised in Table 2 . In order to properly relate these results to their socio-economic context, in-depth interviews were held with 10 agents and tellers, to ask them about their career trajectories, business ideas and activities in a more detailed manner. All interviews were transcribed and systematically analysed to look for cross-cutting themes and patterns and to identify common variables. Through multiple sources of information, involving probing, replication and triangulation with secondary data, a context within which to place mobile money, labour relations and entrepreneurship in Kitwe has been sought. This study provides one empirical case through which to assess 'whether frugal innovation will lead to equitable economic growth or whether it will merely sustain existing inequalities' (Knorringa et al., 2016: 148).

\section{Labour Relations and Entrepreneurship among Mobile Money Agents and Tellers}

The survey results suggest marked differences between agents and tellers in terms of labour relations and entrepreneurship. This section attempts to explain these differences by focusing on educational and employment background of agents and tellers, financing and business operations and the franchising structure of mobile money in Zambia.

\section{Agents and Tellers: Background}

What characteristics differentiate agents from tellers and can these differences explain variations in economic performance? The reception and appropriation of a frugal innovation (such as mobile money) is shaped by intra-community inequalities which determine the ability of individuals to seize economic opportunities (Arora and Romijn, 2012: 489). Agents and tellers differ from each other in terms of age, educational level and job experience and this partially explains their divergent abilities to reap the benefits of mobile money.

Although both mobile money agents and tellers are overwhelmingly young, there is an age difference between them. Whereas all surveyed agents were under 35 years of age, most tellers are even younger and belong to the 18-25 years age group. This fits into trends of youth informalisation throughout Africa, mentioned by Meagher (2016). Mobile money tellers are predominantly recent Grade 12 graduates without previous job experience (Interview \#6, Zoona agent). Their young age facilitates informal labour conditions. Due to high rates of youth unemployment in Zambia (24.6 percent in 2013, https://www.quandl.com/-collections/zambia/zambia-unemployment), tellers are more willing to accept flexibility and they are less likely to object to low wages or long working hours. Agents, contrastingly, are older because they started out as tellers or in other employment some years ago, gaining experience and accumulating capital before setting up their own mobile money businesses. 
In terms of level of education, there is not much difference between agents and tellers when they first start employment. Among both agents and tellers a Grade 12 certificate is the most common level of education (only one teller had dropped out in Grade 10). Yet what does subsequently differentiate them is that upon becoming an agent and saving enough money, some agents go on to pursue college or university degrees. Becoming an agent thus facilitates the pursuit of higher education (in the fields of business, finance, management or public relations), which in turn creates an advantage over other tellers and agents and aids business expansion (Interview \#12, Zoona agent manager). Nonetheless, business success among agents does not appear to be causally linked to level of education. Some agents who earn high profits have a Grade 12 certificate and do not aspire to return to school. One such agent claimed to possess 'business sense', gained through previous work experience in trade (Interview \#9, Airtel and MTN superdealer). Significantly, tellers do not lack educational aspirations and most tellers stated to be saving money for college. Due to high levels of youth unemployment and poverty, working as a teller appears to be an attractive strategy to save money for tertiary education. Yet tellers only rarely regard their employment as part of a 'career path'. Although some tellers aspire to enroll in ICT, business or management courses, many envisage a career in a field unrelated to mobile money, such as education or nursing. Whereas mobile money agents use education to enhance their position as agents and further their business objectives, tellers tend to terminate their employment once they return to school (Interview \#4, Zoona agent and teller). Some agents are thus able to strategically use education within their career paths to attain a certain level of 'elite capture' of the benefits of mobile money, something which tellers are far less well positioned to do (Arora and Romijn, 2012).

Agents and tellers differ markedly when it comes to job experience. Whereas for most tellers their current job constitutes their first employment, all agents have previous job experience. Some agents started out as tellers several years ago, or worked as sales representatives for telecom companies (selling phones, registering SIM cards and advertising promotions). These individuals seized the opportunity to become a mobile money agent, exploiting the 'first mover advantage' as opportunity entrepreneurs (Alvarez and Barney, 2014; Interview \#6, Zoona agent). Other agents came into the mobile money business from unrelated occupations. One agent had previously worked as a cashier in a major supermarket chain, whereas another agent had started out as a fish trader (Interviews \#7 and \#8, MTN and Airtel agents). Prior employment experience can, thus, raise capital and foster the necessary skills to set up as a mobile money agent.

Tellers largely lack such experience, skills and capital, coming straight from secondary school. Still, becoming a teller might be part of a career path, resulting in the opening of a mobile money outlet as an agent. There are examples of tellers who have become agents, predominantly early movers (Interview \#4, Zoona agent and teller). Kitwe's biggest agent has promoted three tellers to become agents, with 
financial support from Zoona. Yet due to a lack of capital, this scenario remains rare. Teller salaries (ranging from K300 to K1,500 per month) are not sufficient to save enough money to open a mobile money outlet. Zoona is the only company that offers selective loans to open an outlet, but these loans are exclusively advertised among agents. Moreover, agents have to back the financial reliability of a teller in order to make them eligible for a loan (Interview \#12, Zoona agent manager). In an example of elite capture, agents might benefit from keeping an informational gap in place to safeguard their own businesses. Nonetheless, most tellers do not even seem to aspire to become agents. Secondary school graduates might become tellers to avoid unemployment, to contribute to household income or to save money for tertiary education, but only few consider mobile money to be a long-term career path. Most tellers would prefer to further their education rather than set up as an agent, especially because the skills obtained as a mobile money teller are not easily transferrable to other sectors (Interview \#5, MTN teller). The result is that most tellers are employed on a short-term basis (working for six months to one year) under poor labour conditions (working long hours for low salaries). This informalisation drives a further wedge between mobile money tellers and agents. Although agents and tellers are initially similar in terms of age, education and job experience, their contingent career paths subsequently cause a gap in capital, experience and information, which enables agents to more easily capture the benefits of mobile money entrepreneurship. Yet not all mobile money agents perform well and in order to differentiate successful from less successful agents it is important to look at factors of financing, business operations and market construction.

\section{Financing, Business Operations and Market Construction}

For agents, financing is a key element in setting up and managing their mobile money business. Zoona requires a minimum capital of K1,500, whereas MTN and Airtel require K3,000 from agents before opening an outlet, prohibitively large sums of money for most 'emerging entrepreneurs' (Interviews \#11 and \#12, MTN and Zoona agent managers). Agents typically adopt one of three strategies to raise starting capital. First, agents can save money to open a kiosk through previous employment, for example by working as a teller. Second, some agents use social capital to generate financial resources (one agent was financed by her father's maize mill). Third, Zoona provides a selective loan scheme to boost the entrepreneurial ability of aspiring agents, allowing them to set up their business and repay the loan from commissions (Interview \#12, Zoona agent manager). Airtel and MTN, however, do not provide any loans to their agents and hold them responsible for managing their own finances. Initial financing directly

affects entrepreneurial opportunities, determining whether an agent can open a high-profit retail shop (a grocery, computer shop or mobile phone outlet where mobile money is combined with other sales activities) or a kiosk (a metal or cardboard structure solely meant for mobile financial services). Apart 
from starting capital, mobile money relies on continued investment to ensure business growth and sustainability.

Mobile money providers frame agents as entrepreneurs and business owners, responsible for the sound financial management of their own outlets. Yet financial management, especially reinvestment in the mobile money business, often proves to be problematic and differentiates successful from failed agents (Interview \#9, Airtel and MTN superdealer). Agents who regard mobile money as a financial opportunity which should be maximally exploited, who hope to make quick profits by immediately pulling out earnings from their outlets, tend to struggle and some go out of business within six months of opening. If agents run out of cash or float (the store of e-money in an agent's account) they are forced to turn down customers. For example, if a customer wants to withdraw K2,000 and this amount of money is not available in the kiosk, the agent or teller has to send the customer to another outlet, causing business loss, reputational damage and decreased profits, especially if this proves a recurring issue (Interview \#10, MTN agent). Agents who do invest in building their float can, conversely, gradually expand their business, by conducting large transactions on which high profits can be made (See Table 1). The busiest agents in Kitwe concur that mobile money is not about making quick profits, but about investing in your business. Some agents use side businesses to build their float. One agent sells mobile phones and registers SIM cards, another agent sells handbags, hair and lingerie (Interview \#9, Airtel and MTN superdealer). Running multiple businesses can raise profits and spread risks, because if an agent's mobile money account runs short it can be balanced with money from other sales. Sound financial management, indispensable for a successful mobile money business, is not a formal skill learnt through school or training, but is rather an entrepreneurial trait which some agents possess more than others (Interview \#6, Zoona agent).

Business success also depends on building the social structure of a new market. The market is a thoroughly social space and 'social structure and relationship development' may well lead 'to improved economic productivity and exchange' (McKague et al., 2015: 1086). Good customer relations are fundamental to building a market for mobile money and in this sphere agents and tellers play an indispensable role, by welcoming customers, politely responding to their requests and making small talk (Interview \#4, Zoona teller and agent). Especially for first-time users it is important to explain how mobile money works step by step, in order to establish trust and to create customer loyalty. In an instrumental view, agents might be seen as mere tools to expand the customer and profit base for network operators, by facilitating scaling and ensuring commercial viability. Yet agents are social actors, 'their knowledge and social infrastructures are important to the maintenance of the bridges to cash; they add something - credibility, reliability - to the mobile channel' (Maurer et al., 2013: 65). Foster and Heeks (2013: 309) note that 'the interaction between agents and customers is anything but a simple market 
transaction, being rooted in a common context of resource constraints, uncertainty, and strong community relationships.' Whereas some agents have relied on existing social networks, others have built a wholly new customer base for mobile money. Kitwe's first agent established herself in the busy Central Business District. By providing good customer care and ensuring reliable transactions, she attracted many loyal customers (Interview \#6, Zoona agent). Another agent targeted minibus drivers, convincing them of the usefulness of mobile money and marketing herself as the most reliable agent (Interview \#10, MTN agent). Others used existing social networks to attract customers, relying on location, reputation or previous employment. One agent in a low-income area simultaneously runs a fish business and due to his good reputation he quickly managed to build a customer base and scale his mobile money business (Interview \#9, Airtel and MTN superdealer). To carve out and consolidate a market, mobile money services have relied on both pre-existing and new social networks.

The location of a mobile money outlet influences business opportunities. The busiest outlets are located in the city centre, around markets and bus stops (Interview \#11, MTN agent manager). Depending on the entrepreneurial initiative of an agent, mobile money outlets can be established in low-income outlying areas. The social network and reputation of the agent is especially important in such locations, as low-income customers are particularly cautious of mobile money. Although customers in outlying areas often have less to spend per transaction, the high volume of transactions can still make business profitable (Interview \#9, Airtel and MTN superdealer). Mobile money can thus be scaled by entrepreneurial agents who are willing to establish themselves in low-income areas. Even though financing, business and markets are structured by the Zambian economy at large, entrepreneurial agents have the ability to shape these structures and create profitable businesses.

\section{Franchising and Labour Relations}

Numerous benefits of franchising are hailed in the literature, including 'job creation, development of SMEs, economic growth, increase of local entrepreneurship, alleviating poverty, and improving managerial capabilities and skills of the labor force' (Sigué, 2012: 168). More negatively, franchising and the agent network of mobile money might simply be another way for service providers to reduce costs, scale among new customers and control risks (Mas and Siedek, 2008). There is a delicate balance of (in)dependence in company-agent relationships. Airtel, MTN and Zoona give the right to use their brand name to mobile money agents, who function as independent retailers. Agents enjoy a large degree of freedom to run their businesses according to their own insights, even if they do have to follow certain company rules and regulations, for example regarding transaction procedures, commission structures or security regulations (anti-money laundering rules). In exchange for any support that agents receive (branding, marketing or training) they surrender part of their commissions to the mobile money provider 
(See Table 1). Agents are held responsible for managing their own finances, without financial support from mobile money providers. Zoona is the only company that assists its agents through selective start-up loans and float balancing (Zoona Cash), which nonetheless come with stringent repayment conditions. The agent remains responsible for business success or failure and poorly performing agents are not backed by any of the three companies (Interviews \#2 and \#11, Zoona and MTN agent managers). In order to realise benefits from franchising, agents need support from Airtel, MTN and Zoona in the form of training courses, support staff and financial assistance. The franchising relationship, whereby mobile money providers partially divest themselves from agents and hold them financially responsible for making profits through commissions, can have problematic consequences. In the race for commissions, agents have started hiring tellers for minimal wages, without regulated working conditions. The framing of agents as profit-maximising entrepreneurs by mobile money providers has induced informalised labour conditions among tellers (Meagher, 2016).

The franchise model has created a large discrepancy between agents and tellers, as agents are formally contracted by mobile money providers, whereas tellers are informally employed by agents. By hiring tellers without knowing them personally and without monitoring them closely, agents 'consolidate their positions by actively producing others' informality and vulnerability' (Meagher et al., 2016: 475). In an attempt to maximise profits, agents condemn tellers to low salaries, insecure and flexible labour conditions, without long-term contracts and without worker rights (Standing, 2014). These informalised labour conditions are expressed among tellers in numerous ways. First, tellers are poorly paid (between $\mathrm{K} 300$ and K1,500 per month) and have no prospects of wage increases. Second, tellers work long hours (from 08.00-17.00 and beyond, including on Saturdays and Sundays) and they are randomly shifted around various outlets. Third, tellers rarely have a contract which states their rights. Finally, teller turnover is high as most tellers leave their job within one year (Interview \#2, Zoona manager). Tellers are relatively educated, but they have no outlook to be promoted, causing frustration and a lack of motivation. The distinction between agents and tellers in terms of labour conditions was clearly reflected in the survey results, as agents invariably classified themselves as independent business owners whereas tellers saw themselves as employees. Whilst the franchising model enables agents to open several mobile money outlets, which might boost the entrepreneurial abilities and profit margins of individual agents, it also serves to entrench informalised labour conditions among tellers (Interview \#6, Zoona agent). Whereas agents focus on expanding their business, most tellers feel disgruntled with their labour conditions and do not view mobile money as a career path. Understanding this difference between agents and tellers is crucial for engaging in debates on inclusive innovation, entrepreneurship and development.

\section{Inclusive Innovation, Entrepreneurship and Informalisation}


If inclusive innovation revolves around implementing new ideas and creating opportunities that enhance socio-economic wellbeing (George et al., 2012), then entrepreneurship, which is the discovery and exploitation of opportunities, appears an ideal tool to achieve inclusivity. This study has questioned whether mobile money can contribute to employment generation, entrepreneurship and (economic) development, by focusing on the labour relations of agents and tellers in Kitwe. Although entrepreneurship is hailed as a 'panacea for inclusive growth', it might have 'unanticipated negative outcomes' (Hall et al., 2012: 785). Whereas some agents have indeed managed to act as entrepreneurs, tellers face informal labour conditions. This distinction is in part a result of the franchising structure of mobile money, and can in part be attributed to global trends, whereby 'large firms increasingly make use of casual labor and externalize employment as part of corporate strategies of flexible production' (Lindell, 2010). By exploring the different labour positions of agents and tellers, debates on frugal innovation and inclusive development can be advanced.

Entrepreneurs work to seize opportunities and thereby actively change their socio-economic settings, including resource constraints, such as lack of capital, knowledge or skills (Eckhardt and Shane, 2003: 339). Some mobile money agents have succeeded in creating new markets, generating high profits (up to K60,000 per month) and consolidating their competitive advantage through business skills. A study of mobile money agents thus offers an insight into processes of market creation, employment generation and entrepreneurship. Yet not all agents are equally fortunate. Some agents close down their business within months, while others struggle to make ends meet due to the precariousness of their commissionbased income (Interview \#12, Zoona agent manager). Moreover, the franchising relation creates vulnerabilities, connecting agents to network operators in a skewed and dependent manner. Framed as profit-maximising entrepreneurs, agents are burdened with the responsibility of generating commissions, without receiving much formal assistance from Airtel, MTN or Zoona. Neither does the contract between agents and network operators include any social benefits, such as health insurance or pensions. Being a mobile money agent is thus an inherently unstable profession, profitable while things are going well but holding no guarantees for the future. In this connection, narratives of entrepreneurship might 'shift attention from the failure (and profound inequities) of the economic structure in which (...) targets exercise limited economic agency' (Dolan and Rajak, 2016: 527).

When considering the position of tellers, it becomes even more obvious that inequality and displacement can run alongside the BoP promise of inclusion' and entrepreneurship (Dolan and Rajak, 2016: 518). Tellers suffer from 'informalisation', 'in having weak or non-existent labour contracts, no 'rights', no protection, and low or volatile earnings' (Standing, 2014: 973). Mobile money tellers are not able to save sufficient money to advance their education or career, they do not build transferrable skills 
and they have no job security. This causes low work morale, which affects customer relationships and jeopardises trust in the mobile money system. Mobile money might therefore be 'beneficial in terms of new livelihoods, but problematic in terms of its longer-term development impacts' (Carmody, 2012: 8). Whereas the story of some mobile money agents endorses the business view of a 'win-win' scenario through frugal innovation and inclusive development, the story of most tellers paints a much bleaker view of informalisation and inequality (Knorringa et al., 2016). Departing from polarising views on frugal innovation and development, mobile money might create entrepreneurship for some, informalisation for others and give rise to new socio-economic inequalities and shifting power relations.

\section{Conclusions}

Existing studies on the relationship between frugal innovation and development have been ideologically polarised (Knorringa et al., 2016). Whilst some have stressed frugal innovation's contribution to development, others have emphasised processes of adverse incorporation and capitalist exploitation. Through an empirical study of mobile money agents and tellers in Kitwe, Zambia, it has been questioned whether the frugal innovation of mobile money has the potential to become an inclusive innovation. It has been suggested that mobile money can, in some cases, spur entrepreneurship and economic growth among agents. At the same time, mobile money has caused informal labour conditions among tellers, who work long hours for minimal payment. The case of mobile money in Kitwe proposes that frugal innovation cannot be analysed in terms of either development or exploitation. Instead, mobile money might give rise to new and partially unpredictable socio-economic inequalities, among agents and between agents and tellers. Processes of inclusion might be selective, simultaneously fostering differentiation and exclusion (Meagher et al., 2016). Despite the rhetoric of entrepreneurship, agents and tellers have to reckon with the structural inequalities of franchising on which they exert limited control. Detailed empirical case studies, thus, provide an opportunity to reach a more nuanced understanding of the relationship between frugal innovation and development.

Although this is a single case, which cannot easily be generalised, it does suggest that frugal innovation studies should pay more attention to the longer-term and ambiguous outcomes which frugal innovations have on livelihoods and development. Rather than talking about inclusion or exclusion, development or exploitation, these processes might better be perceived as 'structurally integrated with one another in the workings of economies' (Phillips, 2011: 385). Moreover, the role of policy in frugal innovation should receive more consideration. In this case, how might policy manage and mitigate the most unequal outcomes of mobile money labour relations, for instance by establishing a minimum rate of pay or basic labour conditions? How can policies be designed to encourage entrepreneurship as well as 
social inclusion in low-income settings (Hall et al., 2012: 786)? The case of mobile money agents in Zambia suggests that the franchising relationship, though holding some entrepreneurial potential for agents, should be closely monitored to avoid adverse labour relations among tellers. Moreover, network operators need to support agents and tellers with training courses, support staff and financial assistance in order to maximally benefit from mobile money entrepreneurship. All in all, there remains much scope to empirically assess the developmental potential of frugal innovation and thereby to complicate and nuance existing conceptual debates. 


\section{Notes}

${ }^{1} \mathrm{~A}$ full list of interviews is provided at the end of this article.

2 The exchange rate was 1 Euro to 10,127 Zambian Kwacha on 1 September 2015: http://www.xe.com/currencytables/?from=ZMW\&date=2015-09-01

${ }^{3}$ In August 2014 Zoona reported having 650+ agents, 600,000+ customers (those who transact at least once every 90 days) and a monthly average transaction volume of $\$ 25,000,000+$ http://www.m4dimpact.com/analysis/case-studies/zoona

${ }^{4}$ I thank Edna Kabala-Litana for her invaluable research assistance. 


\section{Graphics}

Table 1: Customer transaction charges per provider

\begin{tabular}{|c|c|c|c|c|c|}
\hline & $\begin{array}{l}\text { Zoona } \\
\text { Send (free withdrawal) }\end{array}$ & $\begin{array}{l}\text { MTN } \\
\text { Send }\end{array}$ & Withdraw & $\begin{array}{l}\text { Airtel } \\
\text { Send }\end{array}$ & Withdraw \\
\hline K0 - K50 & K5 & K0.25 & $\mathrm{K} 2.50$ & K0.25 & K2.5 \\
\hline $\mathrm{K} 51-\mathrm{K} 150$ & K10 & K0.25 & $\mathrm{K} 2.50$ & K0.50 & K2.5 \\
\hline K151-K300 & K20 & K0.50 & K5 & K1 & K5 \\
\hline K301 - K500 & K40 & K0.80 & K10 & K1 & K10 \\
\hline K501 - K1000 & K55 & K1 & K20 & K1 & K20 \\
\hline K1001 - K5000 & K100 & $\mathrm{K} 2$ & K30 & K3 & K30 \\
\hline
\end{tabular}

Agent commissions are similarly tiered, constituting a small percentage of total transaction charges (less

than 10 percent). Agent commissions are not publicly available, so definitive figures are lacking.

Table 2: Survey results differentiated between agents and tellers

\begin{tabular}{|c|c|c|}
\hline & Agents (23/52) & Tellers $(29 / 52)$ \\
\hline Age & $<35(23 / 23)$ & $<25(28 / 29)$ \\
\hline Education & $\begin{array}{l}\text { Grade } 12(14 / 23), \\
\text { college/university }(9 / 23)\end{array}$ & Grade $12(28 / 29)$ \\
\hline Job experience & $\begin{array}{l}\text { Mobile sales (7), trade (9), } \\
\text { cashier (3) }\end{array}$ & None $(25 / 29)$ \\
\hline Business financing & $\begin{array}{l}\text { Social capital (8), previous jobs } \\
(11), \text { loans (4) }\end{array}$ & None \\
\hline Customer relations & $\begin{array}{l}\text { Social construction of a } \\
\text { marketplace }\end{array}$ & $\begin{array}{l}\text { Importance of good customer } \\
\text { relationships }\end{array}$ \\
\hline Franchising & $\begin{array}{l}\text { Franchisee, contracted by } \\
\text { mobile money provider }\end{array}$ & $\begin{array}{l}\text { Hired by agent, no relation to } \\
\text { mobile money provider }\end{array}$ \\
\hline $\begin{array}{l}\text { Independent business owner } \\
\text { vs. employee }\end{array}$ & Independent business owner & Employee \\
\hline Salary/Monthly profits & Up to $\mathrm{K} 60,000$ & K300-K1,500 \\
\hline
\end{tabular}




\section{List of interviews}

1. Ryan Silutongwe, Mobile technology professional, Lusaka, 29 July 2015

2. Bob Keating, Zoona manager, Lusaka, 30 July 2015

3. Kirsten, Zoona customer care manager, Lusaka, 1 August 2015

4. Nana, Zoona teller and agent, Kitwe, 7 August 2015

5. David Phiri, MTN teller, Kitwe, 12 August 2015

6. Sandra Jere, Zoona agent, Kitwe, 14 and 20 August 2015

7. Kelvin, MTN agent, Kitwe, 15 August 2015

8. Christopher Ngambi, Airtel agent, Kitwe, 21 August 2015

9. Sydney Makofi, Airtel and MTN superdealer, Kitwe, 23 August 2015

10. Progress Mwansa, MTN agent, Kitwe, 23 August 2015

11. Emily, MTN agent manager, Kitwe, 25 August 2015

12. Mbamwabi, Zoona agent manager, Kitwe, 27 August 2015 


\section{References}

Acs, Z. (2006) How Is Entrepreneurship Good for Economic Growth? Innovations 1(1): 97-107.

Aker, J.C., and Mbiti, I.M. (2010) Mobile Phones and Economic Development in Africa. Journal of Economic Perspectives 24(3): 207-232.

Alvarez, S.A., and Barney, J.B. (2014) Entrepreneurial Opportunities and Poverty Alleviation. Entrepreneurship Theory and Practice 38(1): 159-184.

Arora, S. and Romijn, H. (2012) The Empty Rhetoric of Poverty Reduction at the Base of the Pyramid. Organization 19(4): 481-505.

Carmody, P. (2012) The Informationalization of Poverty in Africa? Mobile Phones and Economic Structure. Information Technologies \& International Development 8(3): 1-17.

Chataway, J., Hanlin, R., and Kaplinsky, R. (2014) Inclusive Innovation: An Architecture for Policy Development. Innovation and Development 4(1): 33-54.

Dolan, C., and Rajak, D. (2016) Remaking Africa's Informal Economies: Youth, Entrepreneurship and the Promise of Inclusion at the Bottom of the Pyramid. The Journal of Development Studies 52(4): 514-529.

Donovan, K. (2012) Mobile Money for Financial Inclusion. Information and Communications for Development 61-73.

Duncombe, R.A. (2014) Understanding the Impact of Mobile Phones on Livelihoods in Developing Countries. Development Policy Review 32(5): 567-588.

Duncombe, R.A. (2012) An Evidence-Based Framework for Assessing the Potential of Mobile Finance in sub-Saharan Africa. Journal of Modern African Studies 50(3): 369-395.

Eckhardt, J.T., and Shane, S.A. (2003) Opportunities and Entrepreneurship. Journal of Management 29(3): 333-349.

Finscope (2015) Finscope Zambia:http://www.boz.zm/Publishing/77/77_FSD_Zambia_- Final\%20II.pdf

Foster, C., and Heeks, R. (2013) Innovation and Scaling of ICT for the Bottom-of-the-Pyramid. Journal of Information Technology 28: 296-315.

George, G., McGahan, A.M., and Prabhu, J. (2012) Innovation for Inclusive Growth: Towards a Theoretical Framework and a Research Agenda. Journal of Management Studies 49(4): 661-683.

Gencer, M. (2010) The Mobile Money Movement: Catalyst to Jump-Start Emerging Markets. Innovations 6(1): 101-117.

Habeenzu, S. (2010) Zambia ICT Sector Performance Review 2009/2010: http://www.researchictafrica.net/publications/Policy_Paper_Series_Towards_Evidencebased_ICT_Policy_and_Regulation_-_Volume_2/Vol\%202\%20Paper\%2017\%20\%20Zambia\%20ICT\%20Sector\%20Performance\%20Review\%202010.pdf

Hall, J., Matos, S., Sheehan, L., and Silvestre, B. (2012) Entrepreneurship and Innovation at the Base of the Pyramid: A Recipe for Inclusive Growth or Social Exclusion? Journal of Management Studies 49(4): 785-812.

Heeks, R., Foster, C., and Nugroho, Y. (2014) New Models of Inclusive Innovation for Development. Innovation and Development 4(2): 175-185.

Heeks, R. (2014) ICTs and Poverty Eradication: Comparing Economic, Livelihoods and Capabilities Models. Development Informatics Working Paper Series, University of Manchester.

Hughes, N., and Lonie, S. (2007) M-PESA: Mobile Money for the "Unbanked" Turning Cellphones into 24-Hour Tellers in Kenya. Innovations 2(1-2): 63-81.

Jack, W., Ray, A., and Suri, T. (2013) Money Management by Households and Firms in Kenya Transaction Networks: Evidence from Mobile Money in Kenya. The American Economic Review 103(3): 356-361.

Jack, W. and Suri, T. (2011) Mobile Money: The Economics of M-PESA. NBER Working Paper No. 16721.

Jansen, H. (2010) The Logic of Qualitative Survey Research and its Position in the Field of Social Research Methods. Forum: Qualitative Social Research 11(2). 
Kabala, E. and Seshamani, V., (2016) Mobile Technology and Poverty Reduction in Zambia: A SWOT Analysis. IOSR Journal of Economics and Finance 7(3): 61-74.

Knorringa, P., Peša, I., Leliveld, A., and van Beers, C. (2016) Frugal Innovation and Development: Aides or Adversaries? European Journal of Development Research 28(2): 143-153.

Lindell, I. (2010) Between Exit and Voice: Informality and the Spaces of Popular Agency. African Studies Quarterly 11(2-3): 1-11.

Mas, I. and Siedek, H. (2008) Banking Through Networks of Retail Agents. http://www.cgap.org/publications/banking-through-networks-retail-agents

Maurer, B., Nelms, T.C., and Rea, S.C. (2013) 'Bridges to Cash': Channeling Agency in Mobile Money. Journal of the Royal Anthropological Institute 19(1): 52-74.

McKague, K., Zietsma, C., and Oliver, C. (2015) Building the Social Structure of a Market. Organization Studies 36(8): 1063-1093.

Meagher, K., Mann, L., and Bolt, M. (2016) Introduction: Global Economic Inclusion and African Workers. The Journal of Development Studies 52(4): 471-482.

Meagher, K. (2016) The Scramble for Africans: Demography, Globalisation and Africa's Informal Labour Markets. The Journal of Development Studies 52(4): 483-497.

Morawczynski, O. (2009) Exploring the Usage and Impact of "Transformational" Mobile Financial Services: The Case of M-PESA in Kenya. Journal of Eastern African Studies 3(3): 509-525.

Murphy, J.T., Carmody, P., and Surborg, B. (2014) Industrial Transformation or Business as Usual? Information and Communication Technologies and Africa's Place in the Global Information Economy. Review of African Political Economy 41(140): 264-283.

Omwansa, T.K., and Sullivan, N.P. (2012) Money Real Quick: The Story of M-PESA. Guardian Books.

Paunov, C. (2013) Innovation and Inclusive Development: A Discussion of the Main Policy Issues. OECD Science, Technology and Industry Working Papers.

Peša, I. (2014) Frugal Innovation in Africa: Technology, Entrepreneurship and Development in Innovation Processes. Working Paper Centre for Frugal Innovation in Africa.

Phillips, N. (2011) Informality, Global Production Networks and the Dynamics of 'Adverse Incorporation'. Global Networks 11(3): 380-397.

Schumpeter, J.A. (1934). The Theory of Economic Development: An Inquiry into Profits, Capital, Credit, Interest, and the Business Cycle.

Sigué, S.P. (2012) The Promises of Franchising in Africa: The Need for a Critical Examination. Journal of African Business 13(3): 168-171.

Standing, G. (2014) Understanding the Precariat through Labour and Work. Development and Change 45(5): 963-980.

Ya'u, Y. (2004) The New Imperialism \& Africa in the Global Electronic Village. Review of African Political Economy 31(99): 11-29. 